\title{
Article \\ Improving of Pyrolysis Oil from Macroalgae Cladophora glomerata with HDPE Pyrolysis Oil
}

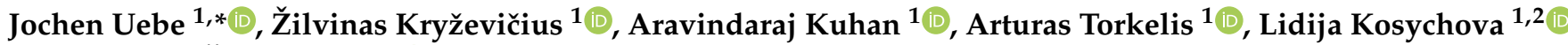 \\ and Audronė Žukauskaitė ${ }^{1}$ (D) \\ 1 Faculty of Marine Technology and Natural Sciences, Klaipeda University, H. Manto, \\ LT-91225 Klaipeda, Lithuania; zilvinas.kryzevicius@ku.lt (Ž.K.); aravindarajkuhan@gmail.com (A.K.); \\ atorkelis@gmail.com (A.T.); lidijakosychova@gmail.com (L.K.); audrone.zukauskaite@ku.lt (A.Ž.) \\ 2 Life Science Center, Institute of Biochemistry, Vilnius University, LT-10257 Vilnius, Lithuania \\ * Correspondence: jochen.uebe@ku.lt
}

Citation: Uebe, J.; Kryževičius, Ž.; Kuhan, A.; Torkelis, A.; Kosychova, L.; Žukauskaitè, A. Improving of Pyrolysis Oil from Macroalgae Cladophora glomerata with HDPE Pyrolysis Oil. J. Mar. Sci. Eng. 2022 10, 131. https://doi.org/10.3390/ jmse10020131

Academic Editor: Azizur Rahman

Received: 12 November 2021

Accepted: 15 January 2022

Published: 19 January 2022

Publisher's Note: MDPI stays neutral with regard to jurisdictional claims in published maps and institutional affiliations.

Copyright: (C) 2022 by the authors. Licensee MDPI, Basel, Switzerland. This article is an open access article distributed under the terms and conditions of the Creative Commons Attribution (CC BY) license (https:// creativecommons.org/licenses/by/ $4.0 /)$.

\begin{abstract}
The slow pyrolysis of macroalgae at moderate temperatures in the reactor used resulted in an oil with a slightly better calorific value than that of the literature, but the other properties were not convincing. Therefore, co-pyrolysis with HDPE offers a way out in this study. However, this did not improve the property profile as a fuel, as the co-pyrolysate was incombustible due to its high water content. Only a mixture of the pyrolysis oil from algae and of the HDPE wax from the initial pyrolysis of HDPE resulted in a diesel-like product: the density was from $807 \mathrm{~kg} \mathrm{~m}^{-3}$, the viscosity $3.39 \mathrm{~mm}^{2} \mathrm{~s}^{-1}$, the calorific value was $46 \mathrm{MJ} \mathrm{kg}^{-1}$, and the oxidation stability was $68 \mathrm{~min}$. The isoparaffin index indicates only a low branching of the paraffins, and therefore a low research octane number of 80 . The blend did not need any further stabilizing additives.
\end{abstract}

Keywords: low-temperature slow pyrolysis; HDPE; macroalgae; Cladophora glomerata; blends

\section{Introduction}

By 2020, the EU aims to produce 10\% of all European fuels from renewable sources [1]. At present, numerous works and studies [2,3] have been carried out to replace fossil fuels with fuels from different biomass. However, much of the biomass used for biofuel production is grown in landlocked areas or could be used elsewhere-such as rapeseed or wheat in the food industry [4].

Based on the current state of knowledge, the use of microalgae is considered as an attractive raw material for the production of biofuels. Although plants and algae have a similar photosynthetic apparatus, algae have several advantages over higher plants in terms of biofuel production [5]. The aquatic way of life does not compete with the area needed for food production. The higher growth rate of many forms of aquatic biomass leads to faster mass production, and the problems associated with land use, such as pollution of rainwater by fertilizers and pesticides, are reduced [6].

Algae can be differentiated into micro and macro forms [7]. Microalgae consist of single or few cellular forms up to a size of a few micrometers, while macroalgae are multicellular, up to $50 \mathrm{~m}$. Macroalgae generally have fibrillary inclusions of polysaccharides such as cellulose to stabilize the cell walls, similar to those of land plants, but often not to the same high order as land plants. Other polysaccharides such as mannans, alginic acid, xylans, and sulphonated polysaccharides also occur. In microalgae, such cell-wall strengthening structures occur in small amounts [7]. The chemical composition of algae, as per all living things, is made up of the three main components: protein, carbohydrates, and lipids. While microalgae often have a higher lipid and protein content, macroalgae have a higher content of carbohydrates [8].

The property of bio-oils from algae is probably better suited for fuel use than that of bio-oils from lignocellulosic materials [9]. However, the quality of algal pyrolysis oils depends on the 
type of algae and the conversion methods and their specific production parameters [10,11]. Algae pyrolysis oils display a higher percentage of cyclic oxygenates [12] because algae contain higher levels of proteins, lipids, nitrogen, and ashes compared to vegetal biomasses [13]. The primary reactions of amino acids during the pyrolysis process are deamination, dehydration, and decarboxylation reactions resulting in N-heterocyclic products [14]. Alcohols, long chain compounds, O-heterocyclic products, and phenols are products of carbohydrate pyrolysis due to the primary decomposition reactions dehydration, cleavage of the glycosidic bond, ring splitting, and rearrangement [15]. Lipids decarboxylate, decarbonylate, and fragment into long chain, alcohol, and alicyclic products [14].

The oil thus produced from biomass has the potential to replace fossil fuels. However, due to its high oxygen and nitrogen content, it needs to be refined. The high oxygen and nitrogen content causes a low calorific value, corrosion problems [16], and instability during storage. In general, it is assumed that these disadvantages can be countered by adding a catalyst, a solvent, and/or a large amount of hydrogen, but this increases the production costs. A simple and effective way to produce a high-quality pyrolysis oil could be the co-pyrolysis of combining biomass with synthetic polymers as an option to improve the oil quantity and quality. Because the polymers are petroleum products, they contain less oxygen and offer a calorific value comparable to that of conventional fossil fuels [6,17].

Plastics are cost-effective, durable, and versatile, which is why their use in manufacturing and meeting various consumer needs is considered favorable. However, plastics are not biodegradable and therefore pose a threat to the environment and society. Energy recovery (pyrolysis) is an innovative technology for the disposal of plastic waste, which has recently attracted a considerable interest in research [18].

High-density polyethylene (HDPE) could serve as a source of hydrogen for the refining of bio-pyrolysis oil, as it was shown by $[19,20]$. It contains a long linear chain of polymerized ethylene. In general, the cleavage reactions of HDPE lead to smaller olefinic chains and gases. As the temperature is increased, more cleavage occurs in the polymer chain, resulting in a high number of short primary radicals that undergo successive $\beta$ cleavage reactions and eliminate small molecules. In addition, the higher concentration of radicals favors intermolecular hydrogen transfer (the higher concentration increases the probability of a bimolecular reaction) to produce alkanes. Secondary reactions at higher temperatures result in the formation of aromatic and polyaromatic compounds without heteroatoms, as it would with algae. Various mechanisms are proposed to explain the formation of benzene and other aromatic compounds, such as combination reactions between conjugated dienes and unsaturated compounds with subsequent dehydrogenation [21,22]. The pyrolysis product of HDPE also contains very little sulfur, which makes it clean for the environment [23].

In this paper, slow pyrolysis is used for decomposition of feedstocks. Slow pyrolysis is the thermal decomposition of the organic components of the biomass in the absence of oxygen at moderate temperatures. It is traditionally used for the production of charcoal, where the vapors are either released into the atmosphere or burned. Product yields depend, in particular, on the composition of the feedstock [24], the dimensions of the feed particles [25], the heating rate, and the final temperature [26], and the total reaction time [27] gives an overview of pyrolysis processes currently tested in industry, even at low temperatures, and their state of development $[28,29]$. The char product is similar for each feedstock at a given temperature, although the yields of gas, pyrolytic oil, and char can be quite different [30,31]. However, recent developments in the field of slow pyrolysis show that, especially, the long duration of heat transfer and better control of inlet and outlet flow rates (controlled product collection) can be an advantage of slow pyrolysis over fast pyrolysis to increase the production of high-quality liquid products [32].

For this work, HDPE and the macroalga Cladophora glomerata from the Baltic Sea were selected for slow pyrolysis in an unstirred batch reactor under normal pressure. Both components are first separated and then co-pyrolyzed to investigate synergistic effect in terms of a slow pyrolysis process at low temperature, product yield, and oil properties. A comparison with a blend of the individual pyrolysis oils was also studied. This promotes 
understanding in relation to the development of applications of (co)pyrolysis products as an energy source and technology with improved value.

\section{Materials and Methods}

\subsection{Materials}

The macroalgae Cladophora glomerata were collected at the northern beach of Klaipeda (Lithuania) and then dried in open air. The algae had a residual moisture content of 5\%. The lignocellulose composition of the collected macroalgae Cladophora glomerata is as in Table 1.

Table 1. The lignocellulose composition of the collected macroalgae Cladophora glomerata.

\begin{tabular}{ccc}
\hline Compound & Analysis Method & Content in \% \\
\hline Cellulose & Kürschner method & $34.5 \pm 1.6$ \\
Lignin & Klason method & $18.5 \pm 2.1$ \\
Hemicellulose, water-soluble & {$[33,34]$} & $45.6 \pm 2.8$ \\
Hemicellulose, water insoluble & {$[33,34]$} & $1.2 \pm 0.1$ \\
Minerals & Calculated by difference & $0.2 \pm 0.1$ \\
\hline
\end{tabular}

HDPE were used from washed and pure plastic waste from a secondary sorting plant (JSC Waste Management Center of Klaipeda Region). Waste HDPE was washed with water and dried. The HDPE and algae were cut into small pieces. The material was roughly mixed by hand before being charged into the reactor.

\subsection{Procedure of Pyrolysis}

Pyrolysis was carried out at atmospheric pressure in a 4.5-liter steel nonstirred batch reactor (internal height $295 \mathrm{~mm}$, internal diameter $190 \mathrm{~mm}$ ) with a single outlet. The thermocouple in a sleeve protrudes $140 \mathrm{~mm}$ from the top into the reactor chamber. The reactor stands upright in the muffle furnace with the reactor head (60 $\mathrm{mm}$ of inner height) protruding from the furnace. The outlet from the cover plate at the reactor head opens via an air-cooled connector into a double neck attachment which sits on a piston for the pyrolysis oil and is connected at the second neck to a water-cooled reflux condenser (about $15{ }^{\circ} \mathrm{C}$ temperature). The reflux condenser is only used for complete condensation of pyrolysis oil. The furnace heats the bottom and the side wall of the reactor to the desired temperature.

The reactor was charged with $500 \mathrm{~g}$ of the single or mixed material by pressing in and pyrolysis was performed at 300,350 , or $400{ }^{\circ} \mathrm{C}$. Mixed materials for co-pyrolysis were mixed in algae/HDPE 30/70, 50/50, or 70/30 ratios, so that the total quantity was $500 \mathrm{~g}$. After closing and connecting the reactor, it was placed in the furnace and connected to the connecting piece to the flask and reflux cooler. The heating rate was $2-3{ }^{\circ} \mathrm{C} \mathrm{min}^{-1}$ with an average residence time of about $2 \mathrm{~h}$, with the temperature in the reactor rising after about 15 min after switching on. When the furnace is switched on and the final temperature has been reached, it is maintained at this temperature until no further drop of condensate flows into the flasks within a time interval of $10 \mathrm{~min}$. The condensed liquid product (pyrolysis oil) was collected in a receiving flask made of glass; the gas was released into the atmosphere through the tube installed in the reactor; the solid residue remained in the reactor and was removed from it at the end of the process. The liquid phase was filtered through Whatman No. 4 filter paper to remove solids and placed in a refrigerator until further analysis. The pyrolysis was realized in three replicates.

The mass balance was determined as the difference between the weight of the sample minus the sum of the liquid, and the solid was equal to the amount of gas.

\subsection{Blending}

The individual pyrolysis oils of the algae Cladophora glomerata and the HDPE waste were mixed in three different algae/HDPE oil ratios: 5 to 95, 10 to 90, and 15 to 85 percent, 
respectively. Preliminary tests have shown that mixtures of up to $25 \%$ algae pyrolysis oil can be mixed in HDPE pyrolysis oils by stirring without phase separation.

\subsection{Distillation of the First Charge of HDPE Pyrolysis Oil}

The pyrolysis oil was distilled by separating the fraction boiling at $190{ }^{\circ} \mathrm{C}$ (hereinafter referred to as the gasoline fraction) and the fraction boiling at $190-320^{\circ} \mathrm{C}$ (diesel fraction). The substance remaining in the vessel after the atmospheric distillation is a wax portion $\left(>320^{\circ} \mathrm{C}\right)$.

\subsection{Second Pyrolysis}

For the second pyrolysis of the wax portion of the first charge of HDPE pyrolysis oil residue (see previous Section 2.4), the reactor was charged with $500 \mathrm{~g}$ of the HDPE wax and pyrolysis was performed at $400^{\circ} \mathrm{C}$. The rate of temperature rise was $2.7^{\circ} \mathrm{C} \mathrm{min}{ }^{-1}$ with a processing time of $160 \mathrm{~min}$. The product is called HDPE wax pyrolysis oil to distinguish it from the HDPE pyrolysis oil from the first pyrolysis.

Blending is performed without further preparation by mixing pyrolysis oil from algae with pyrolysis oil from the second pyrolysis of the HDPE wax in a ratio of $15 \%$ to $85 \%$ or $25 \%$ to $75 \%$.

\subsection{Chemical Properties of Pyrolysis Liquids}

NMR spectral analysis of pyrolysis oil ${ }^{1} \mathrm{H}$ and ${ }^{13} \mathrm{C}$ NMR spectra were recorded on a VarianUnity Inova 300 spectrometer at $302 \mathrm{~K}\left(29^{\circ} \mathrm{C}\right)$ after filtration and with a $16,000 \mathrm{~Hz}\left({ }^{1} \mathrm{H}\right)$ and $210,000 \mathrm{~Hz}\left({ }^{13} \mathrm{C}\right)$ spectral width, $30^{\circ}$ pulse length, and the repetition time $5.1 \mathrm{~s}\left({ }^{1} \mathrm{H}\right)$, and $3.4 \mathrm{~s}\left({ }^{13} \mathrm{C}\right)$ to avoid signal saturation. The chemical shifts $(\delta)$ of the hydrogen and carbon atoms of the pyrolysis oil were referenced to tetramethylsilane (TMS, $\delta=0 \mathrm{ppm}$ ) in deuterated chloroform $\left(\mathrm{CDCl}_{3}\right)$ with a chemical shift $\delta=7.26 \mathrm{ppm}$ for ${ }^{1} \mathrm{H}$ NMR spectra and $\delta=77.0 \mathrm{ppm}$ for ${ }^{13} \mathrm{C}$ NMR spectra.

The amount in vol \% of the aromatics, paraffins, and the olefins are determined by using the signal intensity by integration as given in [32]. The $H / C$ ratio, isoparaffin index, and the research octane number $(\mathrm{RON})$ value of the pyrolysis oils are determined using the following equations from [32]:

$$
\begin{aligned}
& \text { Aromatics, vol } \%=\frac{97(A+C / 3)}{0.97(A+C / 3)+1.02(D-2 B+E / 2+F / 3)+3.33 B} \\
& \text { Paraffins, vol } \%=\frac{102(D-2 B+E / 3+F / 3)}{0.97(A+C / 3)+1.02(D-2 B+E / 2+F / 3)+3.33 B} \\
& \text { Olefins, vol } \%=\frac{333 B}{0.97(A+C / 3)+1.02(D-2 B+E / 2+F / 3)+3.33 B} \\
& \qquad \frac{H}{C}=\frac{A+B+C+D+E+F}{1.28(A+C / 3)+1.02(D-2 B+E / 2+F / 3)+3.42 B} \\
& \text { Isoparaffin index }=\frac{C H_{3}}{C H_{2}}=\frac{(F / 3)}{(E / 2)}
\end{aligned}
$$

These equations were developed to measure the quality of performance of a limited amount of fuel by conventional chemical instrumentation without the need for expensive and time-consuming tests with engines compared to a standard fuel.

\subsection{Physical Properties of Pyrolysis Liquids}

The density was determined according to EN ISO 12185 using a DMA 4500 densimeter. Viscosity was determined according to EN ISO 3104 using a capillary viscometer at $40^{\circ} \mathrm{C}$. The calorific value was determined according to DIN 51900:2000 using an IKA C500300C 
calorimeter. The ash content was analyzed according to EN ISO 6245. Oxidative stability was determined according to EN 16091 using an automatic oxidation stability analyzer PetroOXY from Anton Paar. The flash point was determined according to EN 22719 standard using an automatic FP93 5G2 analyzer, which allows the determination of the flash point of petroleum products in the Pensky-Martens closed cup. The pour point was determined according to ISO 3016 using a fully automatic CPP 5Gs instrument. The determination of content of $\mathrm{C}, \mathrm{H}, \mathrm{N}$, and $\mathrm{S}$ was performed by the CHNS elemental analyzer "Elementar vario Macro" from Elementar Americas.

\section{Results}

\subsection{Separate Pyrolysis of Macroalgae and HDPE}

First, the temperature dependence of pyrolysis on algae was investigated. Figure 1 shows the yield of the solid, liquid, and gaseous phase after pyrolysis at 300,350 , and $400{ }^{\circ} \mathrm{C}$. It can be seen that the yield of the liquid phase hardly depends on the temperature, while the yield of the solid phase decreases as the proportion of gaseous pyrolysis products increases.

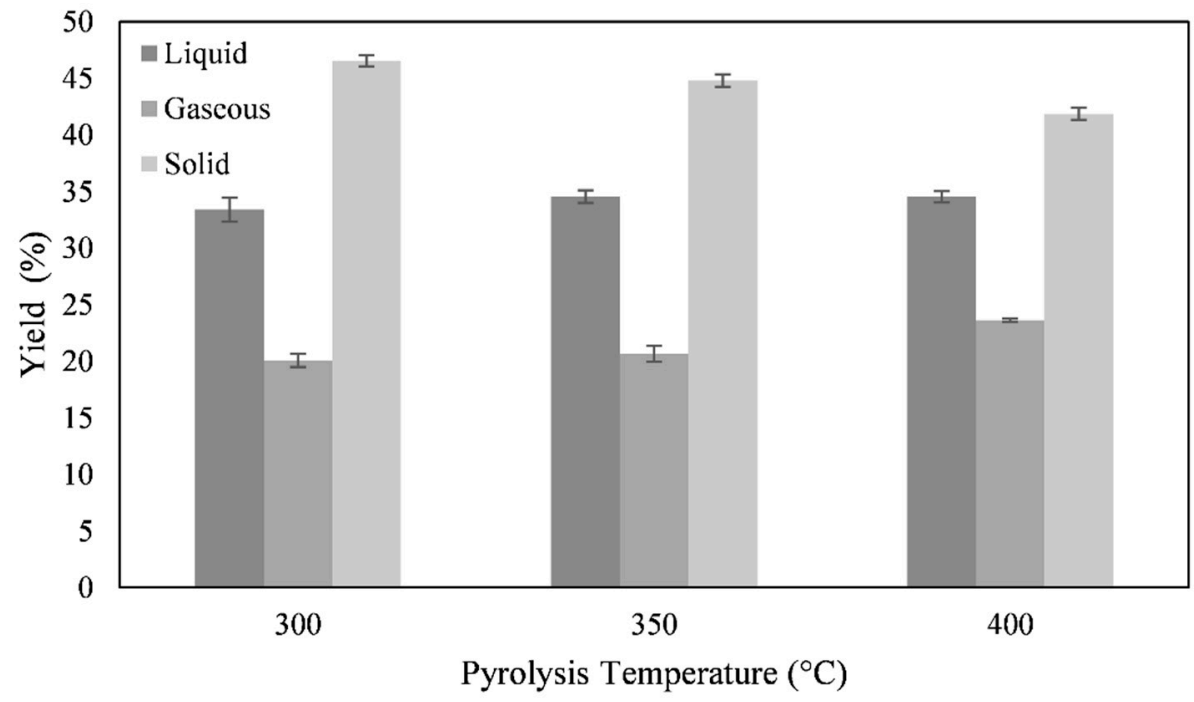

Figure 1. Temperature dependence of the pyrolysis yield of macroalgae.

Figure 2 shows the results of the element analysis of the liquid phase of macroalgae as a function of the three pyrolysis temperatures. Here, it can be clearly seen that the conversion of hydrogen, nitrogen, and sulfur depends only to a very small extent on the temperature, but the conversion of carbon shows a clear maximum at $350{ }^{\circ} \mathrm{C}$.

As the yield of the liquid phase at $400{ }^{\circ} \mathrm{C}$ hardly increases compared to pyrolysis at $350{ }^{\circ} \mathrm{C}$, and shows a clear maximum of carbon conversion from the raw algae into the liquid pyrolysis oil at $350{ }^{\circ} \mathrm{C}$, all subsequent pyrolyses are performed at $350{ }^{\circ} \mathrm{C}$.

Table 2 shows the characteristics of the pyrolysis oils obtained from the macroalgae Cladophora glomerata and from the HDPE waste. The pyrolysis of the algae Cladophora glomerata leads to a high yield of solids and only about 35\% pyrolysis oil that is in accordance with [35]. Furthermore, the pyrolysis of the macroalgae leads to water-containing oil. The water content varies depending on the pyrolysis temperature: $24.4 \pm 0.5 \%$ at $300{ }^{\circ} \mathrm{C}, 18 \pm 0.5 \%$ at $350{ }^{\circ} \mathrm{C}$, as shown in Table 2 , and $6.1 \pm 0.5 \%$ at $400{ }^{\circ} \mathrm{C}$. However, the pyrolysis oil shows no phase separation. The water content of $24.4 \pm 0.5 \%$ at $300{ }^{\circ} \mathrm{C}$ explains the high hydrogen content in the pyrolysis oil at $300{ }^{\circ} \mathrm{C}$. 


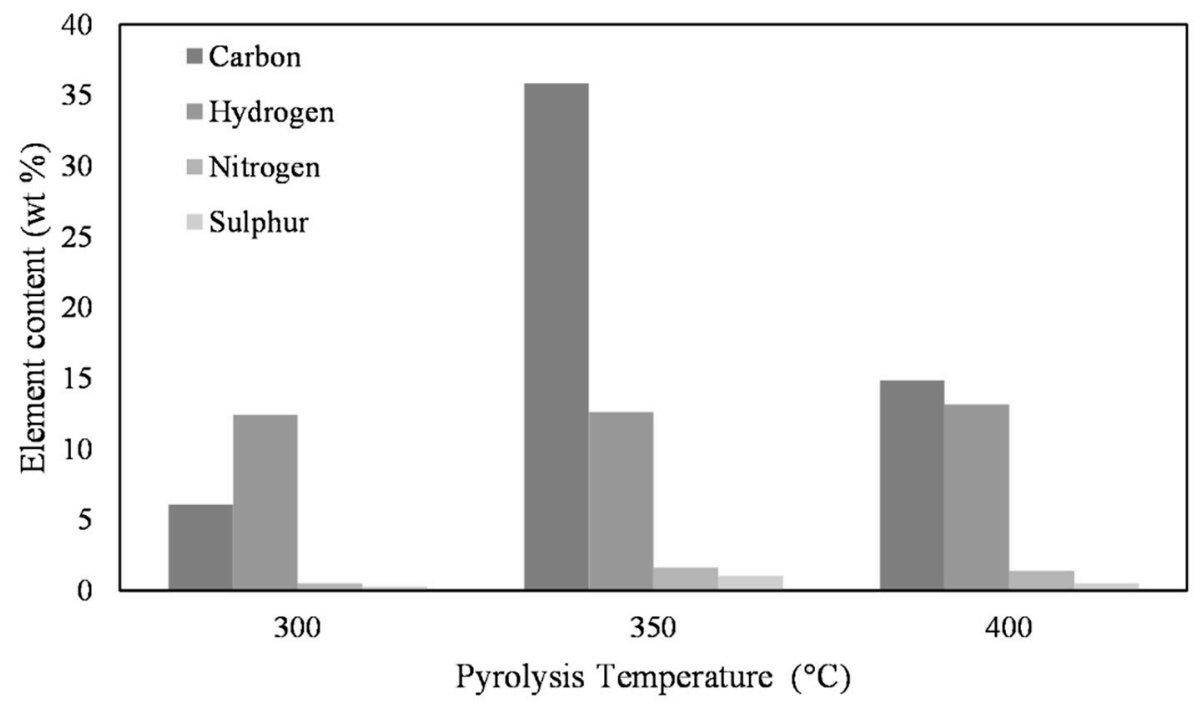

Figure 2. Temperature dependence of the element conversion of the pyrolysis of pure macroalgae into the liquid phase. The difference of the sum of the shown values for C, H, N, and S to $100 \%$ corresponds to the not-shown value for oxygen.

Table 2. Properties of pyrolysis oils from the macroalgae Cladophora glomerata and the HDPE waste at $350{ }^{\circ} \mathrm{C}$.

\begin{tabular}{ccc}
\hline & Macroalgae & HDPE Waste \\
\hline & Yields of pyrolysis (wt \%) \\
\hline Liquid & $34.5 \pm 0.6$ & $76.5 \pm 0.5$ \\
Gaseous ${ }^{*}$ & $20.7 \pm 0.7$ & $13.8 \pm 0.9$ \\
Solid & $44.7 \pm 0.6$ & $9.8 \pm 0.5$ \\
\hline $\mathrm{C}$ & Element analysis of pyrolysis oil (wt \%) \\
$\mathrm{H}$ & 35.82 & 80.45 \\
$\mathrm{~N}$ & 12.62 & 14.76 \\
$\mathrm{O}^{*}$ & 1.60 & 0.35 \\
& 1.05 & 0.27 \\
\hline & 48.91 & 4.17 \\
\hline Density $\left(\mathrm{kg} \mathrm{m}^{-3}\right)$ & Properties of pyrolysis oil & $825 \pm 1$ \\
Viscosity $\left(\mathrm{mm}^{2} \mathrm{~s}^{-1}\right)$ & $992 \pm 1$ & $5.170 \pm 0.007$ \\
Calorific value $\left(\mathrm{MJ} \mathrm{kg}^{-1}\right)$ & $0.984 \pm 0.001$ & $46.0 \pm 1.0$ \\
Water content $(\%)$ & $23.5 \pm 0.6$ & - \\
Ash content $(\%)$ & $18 \pm 0.5$ & $0.0005 \pm 0.0001$ \\
\hline
\end{tabular}

* Calculated by difference.

Because algae are a natural product consisting of proteins, carbohydrates, fats, and various minerals, the typical elements $\mathrm{C}, \mathrm{H}, \mathrm{N}, \mathrm{S}$, and $\mathrm{O}$ are also found in relatively high proportions in the pyrolysis oil. The high ash content is due to the mineral content which is finely distributed in the pyrolysis oil. The literature [36], which has examined algae for their composition of the substance classes, their element distribution, and the conversion of the elements into oil under conditions of slow pyrolysis, reports similar values. The heating value in this study is $23.45 \mathrm{MJ} \mathrm{kg}^{-1}$ at the final pyrolysis temperature of $350{ }^{\circ} \mathrm{C}$ (Table 2), which is twice the value reported in the literature $[18,37]$. This value is about $54 \%$ that of conventional fuel (43 $\mathrm{MJ} \mathrm{kg}^{-1}$ (EN 590)) and also higher than can usually be expected from biomass pyrolysis (about 40\%) [35]. Only the heating values of the algal pyrolysis oil at a final pyrolysis temperature of $300{ }^{\circ} \mathrm{C}, 9.41 \mathrm{MJ} \mathrm{kg}^{-1}$, and at a final pyrolysis temperature of $400{ }^{\circ} \mathrm{C}, 15.12 \mathrm{MJ} \mathrm{kg}^{-1}$, correlate very well with the literature [18,37]. 
The corresponding yields for HDPE pyrolysis oil of this study are similar to those of literature, such as [38]. HDPE is rich in $\mathrm{C}$ and $\mathrm{H}$ and leads to a high yield of pyrolysis oil. A total of $80 \%$ of the carbon from the HDPE waste is converted into oil. The viscosity was a little lower, but the calorific value agreed very well with [39].

\subsection{Co-Pyrolysis Products of HDPE and Macroalgae}

As the pyrolysis oil from macroalgae does not meet the expectations for a fuel with a calorific value of $40-50 \mathrm{MJ} \mathrm{kg}^{-1}$, an attempt was made to increase the calorific value by co-pyrolysis of macroalgae with HDPE. This is a common process, as it is often described in the literature [6,40-42]. Table 3 shows the characteristics of the co-pyrolysis of the algae with HDPE in different mixing ratios. The yield of liquid pyrolysis oil is higher compared to the yield of oil from the pyrolysis of pure algae; it increases with increasing proportion of HDPE to the feedstock. It is also in agreement with the literature [43]. At the same time, the yield of solids decreases with increasing HDPE content in the reactor mixture, while the yield of gaseous products hardly increases with increasing HDPE content.

Table 3. Properties of co-pyrolysis oils from the macroalgae Cladophora glomerata and the HDPE waste at $350{ }^{\circ} \mathrm{C}$.

\begin{tabular}{|c|c|c|c|}
\hline & Algae/HDPE 70/30 & Algae/HDPE 50/50 & Algae/HDPE 30/70 \\
\hline \multicolumn{4}{|c|}{ Yields of pyrolysis (wt \%) } \\
\hline Liquid & $38.6 \pm 0.8$ & $47.8 \pm 0.6$ & $61.1 \pm 0.7$ \\
\hline Gaseous * & $24.0 \pm 1.5$ & $19.3 \pm 1.2$ & $20.7 \pm 0.2$ \\
\hline Solid & $36.9 \pm 0.8$ & $32.8 \pm 0.6$ & $18.2 \pm 0.6$ \\
\hline \multicolumn{4}{|c|}{ Element analysis of pyrolysis oil (wt \%) } \\
\hline C & 2.191 & 4.242 & 4.181 \\
\hline $\mathrm{H}$ & 6.769 & 8.255 & 7.605 \\
\hline $\mathrm{N}$ & 0.204 & 0.315 & 0.341 \\
\hline S & 0.211 & 0.215 & 0.215 \\
\hline $\mathrm{O} *$ & 90.625 & 86.973 & 87.658 \\
\hline \multicolumn{4}{|c|}{ Properties of pyrolysis oil } \\
\hline Density $\left(\mathrm{kg} \mathrm{m}^{-3}\right)$ & $798 \pm 1$ & $830 \pm 2$ & $989 \pm 2$ \\
\hline Viscosity $\left(\mathrm{mm}^{2} \mathrm{~s}^{-1}\right)$ & $0.771 \pm 0.009$ & $0.749 \pm 0.001$ & $1.094 \pm 0.004$ \\
\hline Water content (\%) & $42.4 \pm 0.5$ & $30.1 \pm 0.5$ & $18.2 \pm 0.7$ \\
\hline Ash content (\%) & $1.241 \pm 0.022$ & $1.427 \pm 0.016$ & $1.521 \pm 0.013$ \\
\hline
\end{tabular}

A detailed comparison of the elemental analysis values and the properties of the pyrolysis oils with literature values is not possible, as, to the authors' knowledge, there is no known worldwide co-pyrolysis of Cladophora glomerata with HDPE. Compared to the literature on the co-pyrolysis of other algae species with plastic waste, such as HDPE [44], our pyrolysis oil of the algae/HDPE 50/50 mixture showed lower values for C conversion and density, as in [44].

Carbon conversion to the pyrolysis oil was very low compared to algae pyrolysis, while hydrogen conversion was very high relative to carbon. The oxygen content in the pyrolysis oil was also very high. At the same time, a high water content of the three pyrolysis oils was determined (Table 3), which is probably the cause of the high hydrogen conversion. The large water contents are also reflected in the nondeterminable calorific value of the three algal pyrolysis oils, because these oils could not be ignited. Dehydration (splitting off water) of carbohydrates, i.e., organic substances containing hydroxyl groups, such as cellulose, is one of the primary decomposition reactions in pyrolysis [10]. In most cases, a water content of about $30 \%$ is reported for pyrolysis oil [45-47], in some cases even up to $50 \%[48,49]$. However, this leads to difficulties in the production of fuels, as the high water content makes an additional drying step necessary, as described, e.g., in [49]. In the case of this study, it can be concluded from the high water contents of the co-pyrolyzed oils 
that there is very little interaction between the algae and the HDPE during pyrolysis. The algae pyrolysis in the presence of the HDPE appears to be independent of HDPE pyrolysis. Furthermore, similar to [50], a high water content seems to be more likely to increase the yield of light molecular weight gas and to remove oxygen from organic compounds, as well as to intensively dehydrate the other components in the algae. In this way, the formation of pyrolysis oil would be inhibited during co-pyrolysis. However, ref [50] places this general statement into perspective, because the water content of the pyrolysis oil seems to depend on the algal species. Reference [51] confirms the inhibition of pyrolysis oil formation in the co-pyrolysis of plastic waste with biomass. Here, the bio-oil content was measured as a function of the amount of HDPE in the pyrolysis feedstock, and a strong decrease in bio-oil content was observed. Our results seem to confirm this trend. Therefore, we investigated whether separate pyrolysis with separate mixing of the pyrolysis oils would be a better solution.

\subsection{Blending of Individual Pyrolysis Oils}

As described in the previous Section 3.1, the co-pyrolysis oil from the mixture of macroalgae and HDPE has disadvantages that limit its use as a fuel. Blends of oils can be adapted to the given requirements of engines without the need for extensive technical modifications to the engines. This is especially true for blends with low bio-crude oil and high mineral oil diesel content [52]. There are some examples in the literature [52,53] that show the advantages of such blending. However, it would increase the sustainability of such blends if the mineral diesel content was also replaced by a suitable pyrolysis oil. For HDPE pyrolysis oils, it has already been shown that they can be used as an alternative for mineral oils $[43,54,55]$, especially as the pyrolysis product of HDPE also contains very little sulfur, which makes it clean for the environment and is therefore a more attractive alternative to fossil oils. There is no published literature on the blending and testing of such blends.

Table 4 lists the oil properties of three mixtures of the individual pyrolysis oils of the algae Cladophora glomerata and the HDPE waste.

Table 4. Oil properties of three mixtures of macroalgae and HDPE pyrolysis oils.

\begin{tabular}{cccc}
\hline & Algae/HDPE 5/95 & Algae/HDPE 10/90 & Algae/HDPE 15/85 \\
\hline Density $\left(\mathrm{kg} \mathrm{m}^{-3}\right)$ & $793 \pm 9$ & $803 \pm 2$ & $830 \pm 3$ \\
Viscosity $\left(\mathrm{mm}^{2} \mathrm{~s}^{-1}\right)$ & $2.084 \pm 0.014$ & $2.142 \pm 0.007$ & $1.947 \pm 0.010$ \\
Ash content $(\%)$ & $0.0403 \pm 0.0005$ & $0.0603 \pm 0.0003$ & $0.1034 \pm 0.0025$ \\
calorific value $\left(\mathrm{MJ} \mathrm{kg}^{-1}\right)$ & $43.6 \pm 0.4$ & $37.4 \pm 0.3$ & $35.5 \pm 0.4$ \\
Oxidation stability (min) & $49.9 \pm 0.6$ & $46.6 \pm 0.5$ & $44.2 \pm 0.4$ \\
\hline
\end{tabular}

The more the proportion of HDPE increases, the more the calorific value and oxidation stability increases, whereby the values in comparison with the requirement are clearly above the EN590 standard. The density also decreases with an increased proportion of HDPE oil. The ash content increases with the content of algae oil as the largest source of this. These tendencies of the property changes can be explained by the property profile of the individual oils.

The HDPE pyrolysis oil was used as it was obtained from the pyrolysis furnace. However, when this oil was distilled to separate the highly volatile gasoline and diesel fractions, it was found that the HDPE pyrolysis oil contained a large proportion of wax up to $67 \%$, which is in line with the literature [56-59]. This wax fraction was again pyrolyzed and mixed with algae pyrolysis oil, the oil properties of which are shown in Table 5. The decrease in viscosity, density, and calorific value and the increase in ash content can be explained by the increased algae oil content. The literature [35] states that blends of pyrolysis oils from biomass with mineral oils can only be mixed as emulsions with the aid of additives, which was not the case with the blends of algae and waste HDPE or HDPE wax pyrolysis oils described here. As already mentioned in Section 2.3, preliminary 
tests showed that blends of up to $25 \%$ algae pyrolysis oil in HDPE pyrolysis oils can be mixed by stirring and without additives and show no phase separation. Only with higher proportions of algae does pyrolysis oil show phase separation.

Table 5. Oil properties of two blends of algae pyrolysis oils and of HDPE wax pyrolysis oils (abbreviated Algae and HDPEwax in this table and following Section 3.3.1).

\begin{tabular}{ccc}
\hline & Algae/HDPEwax 15/85 & Algae/HDPEwax 25/75 \\
\hline Density $\left(\mathrm{kg} \mathrm{m}^{-3}\right)$ & $893 \pm 6$ & $807 \pm 6$ \\
Viscosity $\left(\mathrm{mm}^{2} \mathrm{~s}^{-1}\right)$ & $3.710 \pm 0.025$ & $3.390 \pm 0.034$ \\
Ash content $(\%)$ & $0.3143 \pm 0.0087$ & $0.7037 \pm 0.0109$ \\
Calorific value $\left.(\mathrm{MJ} \mathrm{kg})^{-1}\right)$ & $46.6 \pm 0.4$ & $38.4 \pm 0.2$ \\
Oxidation stability (min) & $30.2 \pm 0.3$ & $68.3 \pm 0.6$ \\
\hline
\end{tabular}

Table 5 shows a high oxidation stability for the blend Algae/HDPEwax 25/75. A comparison of the different blends of algae pyrolysis oil with HDPEwaste pyrolysis oil in Table 4 shows that the oxidation stability decreases with an increasing proportion of algae oil from 5 to $15 \%$. In the mixture of 15\% algae pyrolysis oil with the HDPEwax pyrolysis oil, the oxidation stability drops even further, but at a proportion of $25 \%$ it increases significantly. A possible explanation for this could be that the water content in the algae pyrolysis oil only has an effect on the measurement in the sense that the water has a flame-retardant effect at higher contents above 15\%. Pure algae pyrolysis oil, as described in Table 2, has a water content of $18 \%$, so that the blends described in Table 4 had a calculated water content of $0.9 \%, 1.8 \%$, and $2.7 \%$, respectively, and the blends in Table 5 had a calculated water content of $2.7 \%$ and $4.5 \%$, respectively. Water contents of less than $4.5 \%$ in these blends do not yet prevent ignition, unlike co-pyrolysis oils such as those described in Table 3, which have a water content of $18 \%$ or more and could not be tested for their oxidation stability or calorific value. However, it should be noted that the calorific value decreases with increasing algal pyrolysis oil content. This is in accordance with [60] and is not a disadvantage; it even leads to improvements in combustion properties. In contrast to [60], the higher water content in the blends does not lead to higher viscosity.

\subsubsection{Characterization of Blends by NMR Spectroscopy}

Figures 3 and 4 show the ${ }^{1} \mathrm{H}$ and ${ }^{13} \mathrm{C}$ NMR spectra of the blends Algae/HDPE wax 25/75 and Algae/HDPE wax 15/85. By comparison with NMR spectra of the literature [10,32], the following peaks can be assigned to both mixtures:

1. In the aliphatic range: 0.9 ppm (methyl), 1.3 ppm (methylene), 1.6 to 1.8 ppm (betamethine or beta-methylene of branches or naphthenic aliphatics), $2.1 \mathrm{ppm}$ (aromatic alpha-methyl or alpha-methylene).

2. In the olefinic range: 5.8 to $5.9 \mathrm{ppm}$ and at 5.4 to $5.5 \mathrm{ppm}$ (internal double bonds), 4.9 to $5.1 \mathrm{ppm}$ (final double bonds).

According to the high mixing ratio of 75 and $85 \%$ of the HDPE wax pyrolysis oil, respectively, these peaks dominate the ${ }^{1} \mathrm{H}$ NMR spectra (Figures 3a and 4a). These peaks correlate with the few, very intense peaks of the ${ }^{13} \mathrm{C}$ NMR spectra in the range of $0-50 \mathrm{ppm}$ (Figures $3 b$ and $4 b$ ).

The range of aromatic protons is characterized by a large number of peaks with low intensity. The literature for HDPE pyrolysis oil [10,32] suggests that only signals from simple aromatic compounds should occur in this region. Similarly, the literature with NMR analyses of pyrolysis oils from algae and other biomass suggests that they contain a large proportion of aromatics and heteroaromatics $[11,58,59,61,62]$. However, the ${ }^{1} \mathrm{H}$ and ${ }^{13} \mathrm{C}$ NMR spectra of the algae pyrolysis oil (Figure 5) of this work shows many signals in the range of aromatic peaks from 6-9 ppm. 


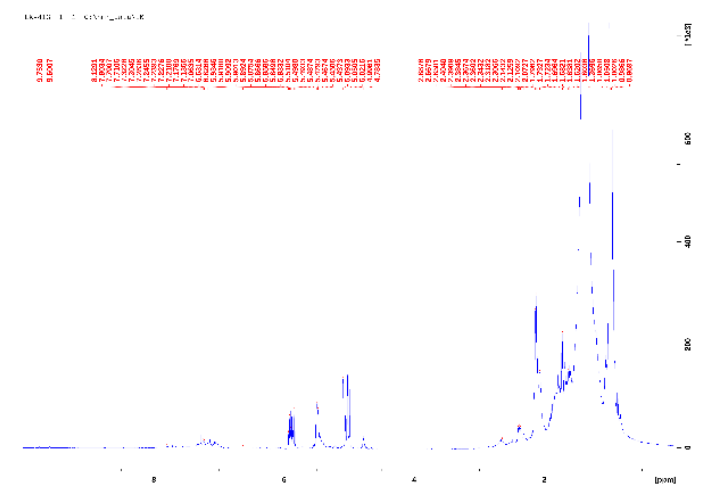

(a)

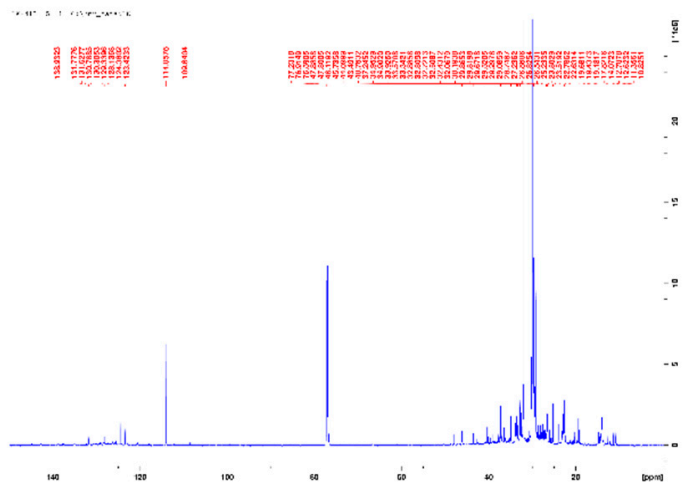

(b)

Figure 3. (a) ${ }^{1} \mathrm{H}$ NMR spectra and (b) ${ }^{13} \mathrm{C}$ NMR spectra of the blend Algae/HDPEwax 25/75.

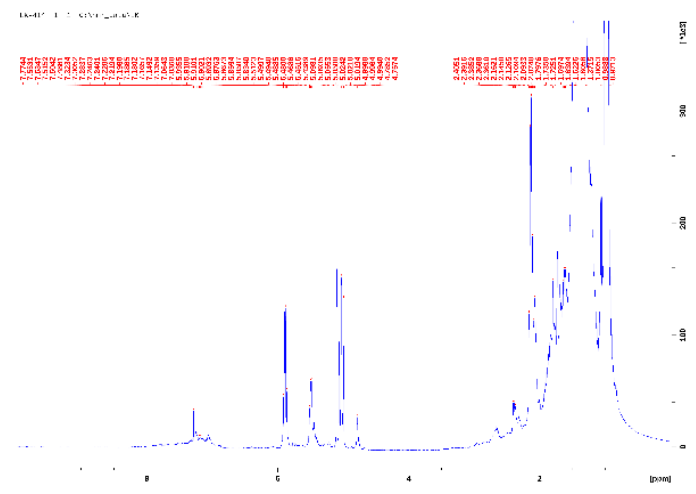

(a)

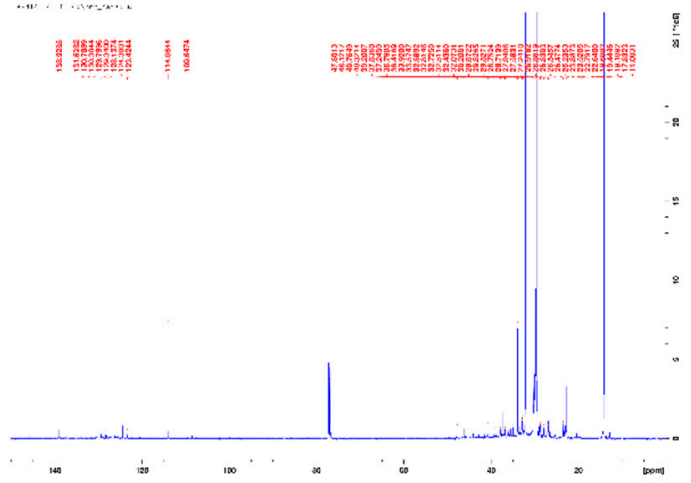

(b)

Figure 4. (a) ${ }^{1} \mathrm{H}$ NMR spectra and (b) ${ }^{13} \mathrm{C}$ NMR spectra of the blend Algae/HDPEwax 15/85.

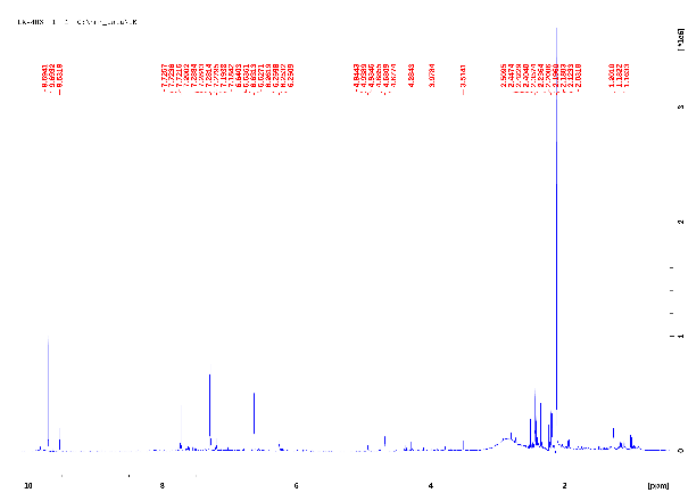

(a)

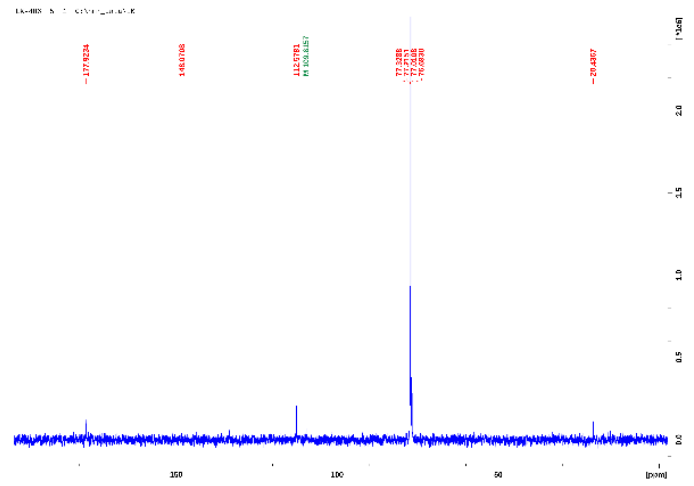

(b)

Figure 5. (a) ${ }^{1} \mathrm{H}$ NMR spectrum and (b) ${ }^{13} \mathrm{C}$ NMR spectrum of the pyrolysis oil of the macroalgae Cladophora glomerata.

Although the pyrolysis of the macroalgae yields a hydrous oil, as shown in Table 2, the water signal is not visible in the NMR spectra with chloroform as solvent because its signal has a chemical shift of about $1.5 \mathrm{ppm}$ and overlaps with the signals of aliphatic protons [63]. From the relatively low peak ${ }^{13} \mathrm{C}$ NMR spectrum of the algae oil in the range of $0-50 \mathrm{ppm}$, it can be concluded that, in particular, aromatic methyl or methylene or methylene protons adjacent to a heteroatom must originate mainly from the HDPE wax pyrolysis oil. This means that the 
subsequent pyrolysis of the HDPE wax not only brought about the intended chain shortening, but also, obviously, caused the formation of presumably aromatic and aliphatic compounds. These results could probably explain the variation in oxidative stability and calorific value of the two blends compared to the blends in Table 5. Double slow pyrolysis of HDPE wax leads to effects that are being further investigated.

NMR spectroscopy is also a very useful tool to calculate chemical and physical properties of petroleum products $[64,65]$. By dividing the spectrum into six regions, integrating the signals of those regions using the scheme and the equations of [32] (Table 6), the fractions of paraffinic, olefinic, and aromatic hydrocarbon in vol \%, as well as the $\mathrm{H} / \mathrm{C}$ ratio, the isoparaffin index, and the RON, were determined from the ${ }^{1} \mathrm{H}$ NMR spectra of the two blends.

Table 6. NMR spectral region and integral area of the two blends Algae/HDPEwax 15/85 and 25/75.

\begin{tabular}{ccccc}
\hline & Proton Type & $\begin{array}{c}\text { Chemical Shift } \\
\text { Region in ppm }\end{array}$ & $\begin{array}{c}\text { Integral Area of Blends } \\
\text { Algae/HDPEwax 15/85 }\end{array}$ & $\begin{array}{c}\text { Integral Area of Blends } \\
\text { Algae/HDPEwax 25/75 }\end{array}$ \\
\hline A & Ring aromatic & $6.6-8.0$ & 0.4426 & 0.4648 \\
B & Olefin & $4.5-6.0$ & 1.8174 & 1.8328 \\
C & a-Methyl & $2.0-3.0$ & 3.6033 & 3.6500 \\
D & Methine (paraffines) & $1.5-2.0$ & 6.5560 & 6.9547 \\
E & Methylene (paraffines) & $1.0-1.5$ & 76.3793 & 74.8678 \\
F & Methyl (paraffines) & $0.6-1.0$ & 11.5252 & 12.9194 \\
\hline
\end{tabular}

The blends mainly show a paraffinic content as it was also found during the analysis of the spectrum based on the functionalities (Table 7). The aromatic content is around 3\% which is the lower limit of commercial fuels [66].

Table 7. Properties of blends determined by ${ }^{1} \mathrm{H}$ NMR spectra.

\begin{tabular}{ccc}
\hline & Algae/HDPEwax 15/85 & Algae/HDPEwax 25/75 \\
\hline Paraffins, vol \% & 85.71 & 85.59 \\
Olefins, vol \% & 11.31 & 11.37 \\
Aromatics, vol \% & 2.98 & 3.04 \\
H/C ratio & 1.85 & 1.85 \\
Isoparaffin index & 0.10 & 0.12 \\
RON & 81.41 & 81.55 \\
\hline
\end{tabular}

An $\mathrm{H} / \mathrm{C}$ ratio of 1.85 is typical for petrol and diesel fuels, which, according to [67], should lead to low greenhouse gas emissions. The isoparaffin index is a measure of the degree of branching of the paraffins in the blends. A high isoparaffin index causes a high octane number of a fuel [68]. The determined isoparaffin indices in this work are low compared to commercial fuels [66]. The RONs show also that the blends need further development for use as fuel. This means that for further improvements, some polymers such as branched polyolefins (e.g., polypropylene or ethylene propylene rubber) should be added to the HDPE feedstock for pyrolysis, so that the isoparaffin index and the RON could be improved as, for example, ref [54] also shows.

\section{Conclusions}

The slow pyrolysis at moderate temperatures has the advantage of low energy consumption. The carbon conversion from the macroalgae Cladophora glomerata as feedstock was most effective at $350{ }^{\circ} \mathrm{C}$ (with respect to the carbon conversion from the algae into the pyrolysis oil) and a pyrolysis oil could be obtained from a feedstock of Cladophora glomerata, which has a calorific value twice as high as described in the literature at $350{ }^{\circ} \mathrm{C}$ after $3 \mathrm{~h}$ pyrolysis. However, as the remaining property profile of the algae pyrolysis oil was unsuitable as fuel, it was co-pyrolyzed from waste plastic with the intention of improving it with HDPE. However, the result was a pyrolysis oil with similar water content as in the absence of the additional HDPE, so that a synergistic pyrolysis as described in the literature can be excluded. 
A blending of pyrolysis oils from HDPE wax or algae feedstock resulted in a good and homogeneous fuel, as the diesel-like product of a blend of $5 \%$ algae pyrolysis oil with $95 \%$ HDPE pyrolysis oil of first pyrolysis shows. At higher algae oil contents of 10 or $15 \%$, the calorific value fell below the level required by the EN590 standard.

Furthermore, the pyrolysis of HDPE from waste plastic after $3 \mathrm{~h}$ pyrolysis at $350{ }^{\circ} \mathrm{C}$ leads to a fuel comparable to the standards for diesel, but this oil still contains about two-thirds wax. After a second pyrolysis, this wax could also be converted to a diesel oil, which led to a significant increase in oxidation stability and flashpoint when blending the HDPE wax pyrolysis oil with the algae pyrolysis oil. This is in contrast to the blends from the HDPE pyrolysis oil of the first pyrolysis with higher contents of algae pyrolysis oil.

The chemical and physical properties of pyrolysis oil from single-component feedstocks and the blends determined by ${ }^{1} \mathrm{H}$ NMR spectroscopy showed the need for further improvements. The RON and isoparaffin indices were too low for use as fuels. These values could probably be improved, e.g., by adding branched polyolefins to HDPE for pyrolysis.

Author Contributions: Conceptualization, A.Ž. and Ž.K.; methodology, Ž.K. and A.Ž.; software, Ž.K.; validation, A.Ž., J.U., L.K. and Ž.K.; formal analysis, A.K., A.T. and Ž.K.; investigation, A.K. and A.T.; resources, Ž.K. and A.Ž.; data curation, L.K., A.K. and A.T.; writing-original draft preparation, J.U., Ž.K. and A.Ž.; writing-review and editing, J.U., Ž.K. and A.Ž.; visualization, Ž.K. and L.K.; supervision, A.Ž. and Ž.K.; project administration, A.Ž.; funding acquisition, A.Ž. All authors have read and agreed to the published version of the manuscript.

Funding: This research received no external funding.

Institutional Review Board Statement: Not applicable.

Informed Consent Statement: Not applicable.

Data Availability Statement: Not applicable.

Conflicts of Interest: The authors declare no conflict of interest.

\section{References}

1. European Commision Technical Assessment of the EU Biofuel Sustainability and Feasibility of $10 \%$ Renewable Energy Target in Transport. Report Renewable Energy Progress Report. 2015. Available online: https://eur-lex.europa.eu/legal-content/EN/ TXT/HTML/?uri=CELEX:52015SC0117\&from=LT (accessed on 26 March 2021).

2. Mathews, J.A. Biofuels: What a Biopact between North and South Could Achieve. Energy Policy 2007, 35, 3550-3570. [CrossRef]

3. Wright, L. Worldwide commercial development of bioenergy with a focus on energy crop-based projects. Biomass Bioenergy 2006, 30, 706-714. [CrossRef]

4. Rathmann, R.; Szklo, A.; Schaeffer, R. Land use competition for production of food and liquid biofuels: An analysis of the arguments in the current debate. Renew. Energy 2010, 35, 14-22. [CrossRef]

5. Rodionova, M.V.; Poudyal, R.S.; Tiwari, I.; Voloshin, R.A.; Zharmukhamedov, S.K.; Nam, H.G.; Zayadan, B.K.; Bruce, B.D.; Hou, H.M.; Allakhverdiev, S.L. Biofuel production: Challenges and opportunities. Int. J. Hydrog. Energy 2017, 42, 8450-8461. [CrossRef]

6. Kositkanawuth, K.; Sattler, M.L.; Dennis, B. Pyrolysis of Macroalgae and Polystyrene: A Review. Curr. Sustain. Reneww. Energy Rep. 2014, 1, 121-128. [CrossRef]

7. Khan, M.I.; Shin, J.H.; Kim, J.D. The promising future of microalgae: Current status, challenges, and optimization of a sustainable and renewable industry for biofuels, feed, and other products. Microb. Cell Fact. 2018, 17, 36. [CrossRef]

8. Suganya, T.; Varman, M.; Masjuki, H.H.; Renganathan, S. Macroalgae and microalgae as a potential source for commercial applications along with biofuels production: A biorefinery approach. Renew. Sustain. Energy Rev. 2016, 55, 909-941. [CrossRef]

9. Yanik, J.; Stahl, R.; Troeger, N.; Sinag, A. Pyrolysis of algal biomass. J. Anal. Appl. Pyrolysis 2013, 103, 134-141. [CrossRef]

10. Balat, M. Mechanisms of Thermochemical Biomass Conversion Processes. Part 1: Reactions of Pyrolysis. Energy Sour. Part A 2008, 30, 620-635. [CrossRef]

11. Ben, H.; Ragauskas, A.J. Comparison for the compositions of fast and slow pyrolysis oils by NMR characterization. Bioresour. Technol. 2013, 147, 577-584. [CrossRef]

12. Vardon, D.R.; Sharma, B.K.; Blazina, G.V.; Rajagopalan, K.; Strathmann, T.J. Thermochemical conversion of raw and defatted algal biomass via hydrothermal liquefaction and slow pyrolysis. Bioresour. Technol. 2012, 109, 178-187. [CrossRef]

13. Debiagi, P.E.A.; TrinchSera, M.; Frassoldati, A.; Faravelli, T.; Vinu, R.; Ranzi, E. Algae characterization and multistep pyrolysis mechanism. J. Anal. Appl. Pyrolysis 2017, 128, 423-436. [CrossRef] 
14. Wang, X.; Sheng, L.; Yang, X. Pyrolysis characteristics and pathways of protein, lipid and carbohydrate isolated from microalgae Nannochloropsis sp. Bioresour. Technol. 2017, 229, 119-125. [CrossRef]

15. Hlavsová, A.; Corsaro, A.; Raclavská, H.; Vallová, S.; Juchelková, D. The effect of feedstock composition and taxonomy on the products distribution from pyrolysis of nine herbaceous plants. Fuel Process. Technol. 2016, 144, 27-36. [CrossRef]

16. Groysman, A. Corrosion problems and solutions in oil, gas, refining and petrochemical industry. Koroze Aochrana Mater. 2017, 61, 100-117. [CrossRef]

17. Abnisa, F.; Wan Daud, W.M.A. A review on co-pyrolysis of biomass: An optional technique to obtain a high-grade pyrolysis oil. Energy Convers. Manag. 2014, 87, 71-85. [CrossRef]

18. Obeid, F.; Janajreh, I. Chapter 47-High Density Polyethylene Pyrolysis: Review and Progress. In ICREGA'14-Renewable Energy: Generation and Applications; Hamdan, M.O., Hejase, H.A.N., Noura, H.M., Fardoun, A.A., Eds.; Springer Nature Switzerland AG: Cham, Switzerland, 2014. Available online: https://www.springer.com/gp/book/9783319057071 (accessed on 26 March 2021).

19. Kusrini, E.; Supramono, D.; Degirmenci, V.; Pranata, S.; Bawono, A.A.; Ani, F.N. Improving the quality of pyrolysis oil from co-firing high-density polyethylene plastic waste and palm empty fruit bunches. Int. J. Technol. 2018, 7, 1498-1508. [CrossRef]

20. Uzoejinwa, B.B.; He, X.; Wang, S.; El-Fatah Abomohra, A.; Hu, Y.; He, Z.; Wang, Q. Co-pyrolysis of seaweeds with waste plastics: Modeling and simulation of effects of co-pyrolysis parameters on yields, and optimization studies for maximum yield of enhanced biofuels. Energy Sour. Part A 2020, 42, 954-978. [CrossRef]

21. Mastral, F.J.; Esperanza, E.; Berrueco, C.; Juste, M.; Ceamanos, J. Fluidized bed thermal degradation products of HDPE in an inert atmosphere and in air/nitrogen mixtures. J. Anal. Appl. Pyrolysis 2003, 70, 1-17. [CrossRef]

22. Liu, X.; Li, X.; Liu, J.; Wang, Z.; Kong, B.; Gong, X.; Yang, X.; Lin, W.; Guo, L. Study of high density polyethylene (HDPE) pyrolysis with reactive molecular dynamics. Polym. Degrad. Stab. 2014, 104, 62-70. [CrossRef]

23. Sharuddin, S.D.A.; Abnisa, F.; Daud, W.M.A.W.; Aroua, M.K. A review on pyrolysis of plastic wastes. Energy Convers. Manag. 2016, 115, 308-326. [CrossRef]

24. Kloss, S.; Zehetner, F.; Dellantonio, A.; Hamid, R.; Ottner, F.; Liedtke, V.; Schwanninger, M.; Gerzabek, M.H.; Soja, G. Characterization of Slow Pyrolysis Biochars: Effects of Feedstocks and Pyrolysis Temperature on Biochar Properties. J. Environ. Qual. 2012, 41, 990-1000. [CrossRef] [PubMed]

25. Suriapparao, D.V.; Vinu, R. Effects of Biomass Particle Size on Slow Pyrolysis Kinetics and Fast Pyrolysis Product Distribution. Waste Biomass Valor. 2018, 9, 465-477. [CrossRef]

26. Li, X.W.C.; Li, Z.; Yu, G.; Wang, Y. Effect of pyrolysis temperature on characteristics, chemical speciation and risk evaluation of heavy metals in biochar derived from textile dyeing sludge. Ecotoxicol. Environ. Saf. 2019, 168, 45-52. [CrossRef]

27. Lechleitner, A.; Schwabl, D.; Schubert, T.; Bauer, M.; Lehner, M. Chemisches Recycling von gemischten Kunststoffabfällen als ergänzender Recyclingpfad zur Erhöhung der Recyclingquote. Österr Wasser-Abfallw. 2020, 72, 47-60. (In German) [CrossRef]

28. Meier, D.; Faix, O. State of the art of applied fast pyrolysis of lignocellulosic materials-A review. Bioresour. Technol. 1999, 68, 71-77. [CrossRef]

29. Qureshi, K.M.; Ng Kay Lup, A.; Khan, S.; Abnisa, F.; Daud, W.M.A.W. A technical review on semi-continuous and continuous pyrolysis process of biomass to bio-oil. J. Anal. Appl. Pyrolysis 2018, 131, 52-75. [CrossRef]

30. Bridgwater, A.V.; Carson, P.; Coulson, M. A comparison of fast and slow pyrolysis liquids from mallee. Int. J. Glob. Energy Issues 2007, 27, 204. [CrossRef]

31. Arni, S.A. Comparison of slow and fast pyrolysis for converting biomass into fuel. Renew. Energy 2018, 124, 197-201. [CrossRef]

32. Das, P.; Tiwari, P. The effect of slow pyrolysis on the conversion of packaging waste plastics (PE and PP) into fuel. Waste Manag. 2018, 79, 615-624. [CrossRef]

33. Obolenskaya, A.V.; Elnitskay, Z.P.; Leonovich, A.A. Laboratory Manual on Wood and Cellulose Chemistry. Ecologia 1991, 250, 237-244.

34. Shulga, G.; Vitolina, S.; Brovkina, J.; Neiberte, B.; Verovkins, A.; Puke, M.; Vedernikovs, N. Wood biomass from the model wastewater and its fractionation. In Environment. Technology. Resources. Proceedings of the 9th International Scientific and Practical Conference, Rezekne, Rezekne, 20-22 June 2013; Rezeknes Augstskola: Rēzekne, Latvia, 2013; Volume 1, pp. 190-194.

35. Bridgewater, T. Challenges and Opportunities in Fast Pyrolysis of Biomass Part I. Johnson Matthey Technol. Rev. 2018, 62, 118-130. [CrossRef]

36. Chaiwong, K. Parametric analyzes of fast-pyrolyzed oil production from algae in a porous bed reactor. Dissertation 2011, 3, 28-39.

37. Plis, A.; Lasek, J.; Skawinska, A.; Zuwała, J. Thermochemical and kinetic analysis of the pyrolysis process in Cladophora glomerata algae. J. Anal. Appl. Pyrolysis 2015, 115, 166-174. [CrossRef]

38. Sogancioglu, M.; Yel, E.; Ahmetli, G. Pyrolysis of waste high density polyethylene (HDPE) and low density polyethylene (LDPE) plastics and production of epoxy composites with their pyrolysis chars. J. Cleaner Prod. 2017, 165, 369-381. [CrossRef]

39. Kumar, S.; Singh, R.K. Recovery of hydrocarbon liquid from waste high density polyethylene by thermal pyrolysis. Braz. J. Chem. Eng. 2011, 28, 659-667. [CrossRef]

40. Martinez, J.D.; Veses, A.; Mastral, A.M.; Murillo, R.; Navarro, M.V.; Puy, N.; Artigues, A.; Bartoli, J.; Garcia, T. Co-pyrolysis of biomass with waste tyres: Upgrading of liquid bio-fuel. Fuel Process. Technol. 2014, 119, 263-271. [CrossRef]

41. Yang, J.; Rizkiana, J.; Widayatno, W.B.; Karnjanakom, S.; Kaewpanha, M.; Hao, X.; Abudula, A.; Guan, G. Fast co-pyrolysis of low density polyethylene and biomass residue for oil production. Energy Convers. Manag. 2016, 120, 422-429. [CrossRef] 
42. Chen, W.; Shi, S.; Zhang, J.; Chen, M.; Zhou, X. Co-pyrolysis of waste newspaper with high-density polyethylene: Synergistic effect and oil characterization. Energy Convers. Manag. 2016, 112, 41-48. [CrossRef]

43. Al-Salem, S.M. Thermal pyrolysis of high density polyethylene (HDPE) in a novel fixed bed reactor system for the production of high value gasoline range hydrocarbons (HC). Process Saf. Environ. Prot. 2019, 127, 171-179. [CrossRef]

44. Xu, S.; Cao, B.; Uzoejinwa, B.B.; Alepu Odey, E.; Wang, S.; Shang, H.; Li, C.; Hu, Y.; Wang, Q.; Nwakaire, J.N. Synergistic effects of catalytic co-pyrolysis of macroalgae with waste plastics. Process. Saf. Environ. Prot. 2020, 137, 34-48. [CrossRef]

45. Chaiwong, K.; Kiatsiriroat, T.; Vorayos, N.; Thararax, C. Study of bio-oil and bio-char production from algae by slow pyrolysis. Biomass Bioenergy 2013, 56, 600-606. [CrossRef]

46. Mostafazadeh, K.A.; Solomatnikova, O.; Drogui, P.; Dayal Tyagi, R. A review of recent research and developments in fast pyrolysis and bio-oil upgrading. Biomass Convers. Biorefin. 2018, 8, 739-773. [CrossRef]

47. Choi, J.H.; Woo, H.C.; Suh, D.J. Pyrolysis of Seaweeds for Bio-oil and Bio-char Production. Chem. Eng. Trans. 2014, 37, 121-126. [CrossRef]

48. Wang, S. Chapter 16-High-efficiency Separation of Bio-oil. In Biomass Now—Sustainable Growth and Use; Matovic, M.D., Ed.; IntechOpen: London, UK, 2013. [CrossRef]

49. McCall, M.J. Production of Chemicals from Pyrolysis Oil. U.S. Patent 8,158,842B2, 17 April 2012.

50. Tang, Z.; Chen, W.; Hu, J.; Li, S.; Chen, Y.; Yang, H.; Chen, H. Co-pyrolysis of microalgae with low-density polyethylene (LDPE) for deoxygenation and denitrification. Bioresour. Technol. 2020, 311, 1235022. [CrossRef] [PubMed]

51. Supramono, D.; Kusrini, E.; Yuana, H. Yield and Composition of Bio-oil from Co-Pyrolysis of Corn Cobs and Plastic Waste of HDPE in a Fixed Bed Reactor. J. Jpn. Inst. Energy 2016, 95, 621-628. [CrossRef]

52. Krutof, A.; Hawboldt, K. Blends of pyrolysis oil, petroleum, and other bio-based fuels: A review. Renew. Sustain. Energy Rev. 2016, 59, 406-419. [CrossRef]

53. Ambrosewicz-Walacik, M.; Wierzbicki, S.; Mikulski, M.; Podciborski, T. Ternary fuel mixture of diesel, rapeseed oil and tyre pyrolytic oil suitable for modern CRDI engines. Transport 2018, 33, 727-740. [CrossRef]

54. Ahmad, I.; Khan, M.I.; Khan, H.; Ishaq, M.; Tariq, R.; Gul, K.; Ahmad, W. Pyrolysis Study of Polypropylene and Polyethylene into Premium Oil Products. Int. J. Green Energy 2015, 12, 663-671. [CrossRef]

55. Istoto, E.H.; Widayat; Saptadi, S. Production of Fuels from High Density Polyethylene and Low Density Polyethylene Plastic Wastes via Pyrolysis Methods. Iran. J. Energy Environ. 2019, 10, 185-189. [CrossRef]

56. Anene, A.F.; Fredriksen, S.B.; Sætre, K.A.; Tokheim, L.A. Experimental Study of Thermal and Catalytic Pyrolysis of Plastic Waste Components. Sustainability 2018, 10, 3979. [CrossRef]

57. Umaru, H.I.; Yakubu, M.K.; Kolawole, E.G.; Baba, M.A. Effect of Pyrolysis Temperature and Time on Wax Production from Waste Polyethene. Asian J. Appl. Sci. 2014, 2, 644-649.

58. Aboulkas, A.; Hammani, H.; El Achaby, M.; Bilal, E.; Barakat, A.; El Harfi, K. Valorization of algal waste via pyrolysis in a fixed-bed reactor: Production and characterization of bio-oil and bio-char. Bioresour. Technol. 2017, 243, 400-408. [CrossRef]

59. Ly, H.V.; Kim, S.-S.; Woo, H.C.; Choi, J.H.; Suh, D.J.; Kim, J. Fast pyrolysis of macroalga Saccharina japonica in a bubbling fluidizedbed reactor for bio-oil production. Energy 2015, 93, 1436-1446. [CrossRef]

60. Kittipoomwonga, P.; Narasingh, M. Emulsification of Water and Pyrolysis Oil. Energy Procedia 2015, 79, 752-758. [CrossRef]

61. Ben, H.; Ragauskas, A.J. Heteronuclear Single-Quantum CorrelationNuclear Magnetic Resonance (HSQCNMR) Fingerprint Analysis of Pyrolysis Oils. Energy Fuels 2011, 25, 5791-5801. [CrossRef]

62. Lyckeskog, N.H.; Mattsson, C.; Olausson, L.; Andersson, S.-I.; Vamling, L.; Theliander, H. Thermal stability of low and high Mw fractions of bio-oil derived from lignin conversion in subcritical water. Biomass Convers. Biorefin. 2017, 7, 401-414. [CrossRef]

63. Gottlieb, H.E.; Kotlyar, V.; Nudelman, A. NMR Chemical Shifts of Common Laboratory Solvents as Trace Impurities. J. Org. Chem. 1997, 62, 7512-7515. [CrossRef]

64. Edwards, J.C. A Review of Applications of NMR Spectroscopy in the Petroleum Industry in Spectroscopic Analysis of Petroleum Products and Lubricants; Nadkarni, R., Ed.; ASTM International: West Conshohocken, PA, USA, 2011; pp. 423-472. [CrossRef]

65. Petrakis, L.; Fraissard, J.P. Magnetic Resonance-Introduction, Advanced Topics and Application to Fossil Engery; D. Reidel Publishing Company: Dordrecht, Holland, 1984.

66. Hancsok, J.; Magyar, S.; Hollo, A. Importance of Isoparaffins in the Crude Oil Refining Industry. Chem. Eng. Trans. 2007, 11, 41-47.

67. Annamalai, K.; Thanapal, S.S.; Ranjan, D. Ranking Renewable and Fossil Fuels on Global Warming Potential Using Respiratory Quotient Concept. J. Combust. 2018, 2018, 1270708. [CrossRef]

68. Demirbas, A.; Balubaid, M.A.; Basahel, A.M.; Ahmad, W.; Sheikh, M.H. Octane Rating of Gasoline and Octane Booster Additives. Pet. Sci. Technol. 2015, 33, 1190-1197. [CrossRef] 